\title{
IMPLIKATUR PERCAKAPAN DALAM PEMBELAJARAN BAHASA INDONESIA PADA PROGRAM STUDI AKUNTANSI SEMESTER I FEB UNMAS DENPASAR
}

\author{
Dewa Gede Bambang Erawan \\ Fakultas Keguruan dan Ilmu Pendidikan, Universitas Mahasaraswati Denpasar \\ Email: bambangerawandewa@gmail.com
}

\begin{abstract}
ABSTRAK
Penelitian ini bertujuan untuk mendeskripsikan implikatur percakapan dalam pembelajaran Bahasa Indonesia Pada Program Studi Akuntansi Semester I FEB Unmas Denpasar, dan faktor - faktor yang menyebabkan munculya implikatur percakapan dalam pembelajaran Bahasa Indonesia pada Program Studi Akuntansi Semester I FEB Unmas Denpasar. Metode penelitian yang digunakan dalam penelitian ini adalah deskriptif kualitatif. Subjek penelitian ini adalah mahasiswa dan dosen dalam mata kuliah bahasa Indonesia pada Program Studi Akuntansi Semester I FEB Unmas Denpasar. Hasil penelitian ini menunjukkan bahwa wujud implikatur percakapan yang ada dalam proses pembelajaran meliputi, implikatur konvensional, implikatur khusus, implikatur umum, dan implikatur berskala. Faktor yang menyebabkan munculnya implikatur percakapan dalam pembelajaran meliputi: bahasa, keakraban, kepekaan, budaya, kepedulian dan kasih sayang.
\end{abstract}

Kata kunci: Implikatur percakapan, Pembelajaran

\section{ABSTRAK}

This study aims to describe the conversational implications of learning Indonesian in the Accounting Study Program Semester I FEB Unmas Denpasar, and the factors that cause the implications of conversation in learning Indonesian at Semester I FEB Unmas Denpasar Accounting Study Program. The research method used in this research is descriptive qualitative. The subjects of this study were students and lecturers in Indonesian language courses in the Accounting Study Program Semester I FEB Unmas Denpasar. The results of this study indicate that the forms of conversational implicatures in the learning process include conventional implicatures, special implicatures, general implicatures, and scaled implicatures. Factors that cause the emergence of conversational implicatures in learning include: language, familiarity, sensitivity, culture, care and affection.

Keywords: Conversational implicature, learning

\section{PENDAHULUAN}

Bahasa merupakan media dalam berkomunikasi. Dalam proses komunikasi tersebut, mutlak terjadi interaksi antara penutur dengan lawan tutur. Interaksi yang terjadi antara penutur dan lawan tutur tidak terlepas dari penyampaian gagasan, baik dengan menggunakan bahasa lisan maupun tulisan. Penggunaan bahasa secara lisan merujuk pada percakapan langsung yang dilakukan oleh penutur kepada mitra tuturnya.

Percakapan yang dilakukan oleh seseorang akan mengandung makna yang tidak sama. Hal tersebut sangat bergantung kepada cara lawan tutur dalam menafsirkan setiap ujaran yang disampaikan oleh 
penutur. Baik penutur maupun lawan tutur, harus sama-sama memahami setiap tuturan yang disampaikan oleh lawan bicaranya sesuai dengan konteks tuturan.

Sebuah percakapan yang terjadi sangat ditentukan oleh konteks, pelaku, (penutur dan lawan tutur) usia, jenis kelamin, tempat terjadinya percakapan dan sebagainya (Yuniarti, 2016). Percakapan yang memiliki makna lain dari ujaran penutur kepada lawan tutur disebut implikatur percakapan. Pengertian tersebut sejalan dengan pendapatnya (Rusminto, 2009) yang menyatakan Implikatur percakapan merupakan sesuatu yang disembunyikan dalam sebuah percakapan, yakni yang secara implisit terdapat dalam penggunaan bahasa secara aktual. Konteks memegang peranan yang sangat penting terkait dengan proses pemahaman terhadap percakapan yang bermakna tidak langsung. Grice (dalam Rusminto, 2009) menyatakan bahwa konteks merupakan latar belakang pengetahuan yang sama-sama dimiliki oleh penutur dan mitra tutur yang memungkinkan mitra tutur untuk memperhitungkan implikasi tuturan dan memaknai arti tuturan dari si penutur.

Implikatur percakapan dapat terjadi dalam konteks formal maupun nonformal. Salah satu bentuk percakapan dalam konteks formal dapat terjadi dalam proses pembelajaran di kelas. Percakapan dalam konteks pembelajaran di kelas merupakan wujud dari interaksi, baik yang dilakukan dosen kepada mahasiswa, maupun antar mahasiswa satu dengan yang lainnya. Percakapan yang dilakukan di kelas khususya dalam pembelajaran memiliki beberapa maksud dan tujuan. Maksud atau tujuan dari tuturan yang disampaikan dapat diketahui berdasarkan konteks dari ujaran tersebut. Tujuan dari setiap ujaran yang terjadi dalam percakapan bisa bermakna sebenarnya, memerintah secara halus, atau dapat juga bermakna sindiran yang harus dikelola dengan bijak oleh guru/dosen. Hal tersebut menjadi penting mengingat perkembangan berbahasa anak dapat dipengaruhi oleh tuturan guru dalam proses belajar-mengajar (Rachman, 2015). Guru/dosen dan mahasiswa seharusnya tetap memperhatikan prinsip kesopanan dalam setiap tuturannya melalui implikatur percakapan dalam konteks pembelajaran di kelas. Implikatur percakapan yang terjadi dalam pembelajaran dengan memegang teguh prinsip kesopanan bertujuan agar semakin eratnya hubungan antara dosen dengan mahasiswa yang berimplikasi bagi efektifitas tujuan pembelajaran.

Penelitian sejenis yang menganalisis implikatur dalam percakapan sudah banyak dilakukan, namun sebagian besar menganalisis implikatur percakapan dalam konteks konfensional (conventional implicature), padahal implikatur percapakan yang terjadi dalam konteks percakapan (conversation implicature) sering juga terjadi dan layak untuk dijadikan sebagai bahan analisis termasuk percakapan yang terjadi dalam proses pembelajaran di kelas.

Pernyataan tersebut sejalan dengan yang dikemukakan oleh Grice (dalam Geoffrey, 1993) yang membagi implikatur menjadi dua jenis, yaitu implikatur konvensional (conventional implicature) dan implikatur percakapan (conversation implicature). Implikatur konvensional yaitu implikasi pragmatik yang diperoleh langsung dari makna kata, bukan dari prinsip-prinsip percakapan. Implikatur konvensional tidak harus terjadi dalam percakapan dan tidak tergantung pada konteks khusus untuk menginterpretasikannya. Sedangkan implikatur percakapan 
memiliki makna dan pengertian yang lebih bervariasi. Pemahaman terhadap "maksud tuturan" sangat tergantung pada konteks terjadinya percakapan. Oleh karenanya, implikatur tersebut bersifat temporer (terjadi saat berlangsung tindak percakapan) dan nonkonvensional (sesuatu yang diimplikasikan tidak mempunyai relasi langsung dengan tuturan yang diucapkan). Dalam hal ini, implikatur menjadi penting untuk dipahami karena dapat menjaga hubungan harmonis antar penutur dan petutur (dosen/guru dengan mahasiswa). Ketika suatu ujaran disampaikan dengan dengan maksud menyindir atau mengkritik secara implisit maka diharapkan tidak muncul kesalahpahaman dan ketersinggungan.

Peneliti tertarik menganalisis implikatur percakapan yang terjadi dalam pembelajaran karena dosen, ataupun mahasiswa tidak menyadari bahwa yang bersangkutan sering menggunakan implikatur percakapan dalam pembelajaran dengan tujuan yang bervariasi (mengkritik, memerintahkan, menyindir), serta menemukan faktor-faktor yang menyebabkan munculnya implikatur percakapan tersebut khususnya dalam pembelajaran. Berdasarkan permasalahan tersebut, maka tujuan penelitian ini adalah menganalisis wujud implikatur percakapan yang digunakan oleh dosen dan mahasiswa dalam proses pembelajaran, serta menemukan faktor-faktor yang menyebabkan munculnya implikatur percakapan dalam pembelajaran bahasa Indonesia pada Program Studi Akuntansi semester I FEB Unmas Denpasar. Hasil penelitian ini diharapkan dapat memperkaya kajian penelitian bahasa Indonesia, khususnya kajian implikatur percakapan. Selain itu agar dapat memberikan informasi kepada mahasiswa bahwa penggunaan implikatur percakapan berkontribusi dalam upaya menjalin hubungan yang lebih kondusif dengan berbagai pihak.

\section{METODE PENELITIAN}

Pendekatan yang digunakan dalam penelitian ini adalah deskriptif kualitatif. Dengan pendekatan tersebut peneliti memaparkan, menggambarkan, dan menganalisis secara kritis, dan objektif dengan data yang otentik bentuk percakapan yang mengandung implikatur dalam pembelajaran bahasa Indonesia pada Program Studi Akuntansi Semester I FEB Unmas Denpasar. Subjek penelitian ini adalah dosen dan mahasiswa yang terlibat dalam pembelajaran bahasa Indonesia pada Program Studi Akuntansi Semester I FEB Unmas Denpasar. Objek penelitian ini merupakan implikatur percakapan dalam pembelajaran bahasa Indonesia pada Program Studi Akuntansi Semester I FEB Unmas Denpasar.

Metode pengumpulan data dalam penelitian ini adalah observasi, perekaman, dan wawancara. Observasi dilakukan dengan cara melakukan pengamatan di kelas yang menjadi tempat pelaksanaan proses pembelajaran. Teknik perekaman bahasa dilakukan dengan alat perekam, yakni handphonel video recorder. Wawancara dilakukan setelah pengamatan (observasi) dan perekaman.

Metode analisis data yang digunakan dalam penelitian ini meliputi, reduksi data, penyajian data, verifikasi data. Reduksi data merupakan proses pemilihan, pemusatan perhatian pada penyederhanaan, pengabstakan, dan transformasi data "kasar" yang muncul dari catatan-catatan tertulis di lapangan. 
Penyajian data merupakan sekumpulan informasi tersusun yang memberi kemungkinan adanya penarikan kesimpulan dan pengambilan tindakan. Verifikasi data adalah pembentukan kebenaran teori, fakta, dsb atas data yang dikumpulkan untuk diolah dan dianalisis agar bisa diuji secara hipotesis.

\section{HASIL DAN PEMBAHASAN}

Implikatur yang terjadi dalam pembelajaran bahasa Indonesia pada Program Studi Akuntansi Semester I FEB Unmas Denpasar meliputi: implikatur percakapan umum, khusus, berskala, dan praangapan yang diimplementasikan dalam sebuah kalimat berupa kalimat deklaratif, imperatif, dan kalimat interogratif. Pada bagian analisis implikatur konvensional, peneliti menemukan dua wujud implikatur yang diklasifikasikan atas wujud tuturan imperatif dan tuturan interogratif. Wujud tuturan imperatif dilihat dari segi gramatikal dan pengucapan yang dilakukan oleh penutur.

Berikut adalah analisis wujud tuturan imperatif dalam implikatur konvensional.

\section{( Tuturan 37 )}

Dosen : "Kalau mau ribut silahkan di luar, tidak papa!"

Konteks : Dosen menyuruh mahasiswa untuk keluar kelas karena kondisi kelas pada saat itu ribut.

Analisis : Maksud dari tuturan tersebut adalah dosen menyuruh Pada bagian analisis implikatur percakapan berskala, peneliti menemukan dua wujud implikatur. Wujud implikatur percakapan berskala tersebut berupa wujud tuturan imperatif dan tuturan interogratif. mahasiswa untuk keluar kelas karena kondisi kelas pada saat itu ribut.

Wujud tuturan interogratif akan dilihat dari segi gramatikal dan pengucapan yang dilakukan oleh penutur. Berikut ini adalah analisis wujud tuturan interogratif dalam implikatur konvensional.

\section{( Tuturan 8 )}

Dosen : "Kamu tahu sumpah pemuda ?"

Konteks : Dosen memberikan punishment kepada mahasiswa yang tidak mengerjakan tugas dengan menyampaikan isi teks Sumpah Pemuda.

Analisis : Maksud dari tuturan tersebut adalah Dosen memberikan hukuman terhadap mahasiswa yang tidak mengerjakan tugas dengan cara melafalkan isi teks Sumpah Pemuda.

\section{( Tuturan 10 )}

Dosen : "Kedudukan dan fungsi bahasa Indonesia itu apakah sama?" "Bagus ada apa?"

Mahasiswa : "Ngeliatin angin bu."

Konteks : Dosen menjelaskan tentang kedudukan dan fungsi bahasa Indonesia, tetapi ada mahasiswa yang tidak memperhatikan.

Analisis : Maksud dari tuturan tersebut adalah Dosen menjelaskan tentang kedudukan dan fungsi bahasa Indonesia, tetapi ada mahasiswa yang tidak memperhatikan.

Berikut ini adalah beberapa data tuturan imperatif yang diwujudkan dalam jenis implikatur percakapan berskala.

( Tuturan 30)

Dosen : " Kira- kira berapa lama membaca sumpah pemuda?" 
Konteks : dosen sedang bernegosiasi terkait dengan materi perkuliahan (tugas).

Analisis : Maksud dari tuturan tersebut adalah dosen sedang bernegosiasi terkait dengan materi perkuliahan (tugas).

\section{( Tuturan 34 )}

Mahasiswa : "Permisi bu ijin mau ke belakang."

Dosen : "Jangan lama - lama. !"

Mahasiswa: "15 menit Bu"

Dosen: 5 menit saja cukup!

Konteks : Dosen ingin mahasiswanya disiplin

Analisis : Maksud dari tuturan tersebut adalah dosen ingin mengajarkan kedisiplinan terhadap mahasiswanya.

Berkaitan dengan fungsi komunikatif wujud interogratif memiliki tujuan untuk memberikan pertanyaan terhadap mitra tuturnya. Berikut ini adalah beberapa data tuturan interogratif yang diwujudkan dalam jenis implikatur percakapan berskala.

( Tuturan 30 )

Dosen : "Kira - kira berapa lama utuk baca sumpah pemuda?"

Analisis : Maksud dari tuturan tersebut adalah dosen sedang bernegosiasi

Mahasiswa : "Satu jam bu."

Dosen: "15 menit saja cukup ya!"

Konteks : Dosen sedang bernegosiasi terkait perkuliahan ( tugas ).

Analisis : Maksud dari tuturan tersebut adalah dosen sedang bernegosiasi terkait perkuliahan ( tugas ).

Pada bagian analisis implikatur percakapan khusus, peneliti menemukan satu wujud implikatur. Wujud implikatur percakapan khusus tersebut berupa tuturan interogratif yang akan disajikan sebagai berikut.

\section{( Tuturan 2 )}

Dosen : "Silahkan dibuka materi 2 " Mahasiswa: "Katanya ujian lisan bu?"

Konteks : Dosen menyuruh mahasiswa untuk membuka buku di bab dua, sedangkan MahaMahasiswa mengingatkan bahwa hari ini akan diadakan ulangan lisan.

Analisis : Maksud dari tuturan tersebut adalah dosen menyuruh mahasiswa untuk membuka materi kedua, sedangkan mahasiswa mengingatkan bahwa hari ini akan diadakan ulangan lisan.

\section{( Tuturan 28 )}

Dosen : “ Agung lagi sakit ya ? kok makek jaket?

Konteks : Dosen menyuruh Agung untuk melepas jaket sesuai dengan aturan kampus.

Analisis : Maksud dari tuturan tersebut adalah dosen menyuruh Agung untuk melepas jaket sesuai dengan aturan kampus.

Pada bagian analisis implikatur percakapan umum, wujud implikatur percakapan umum tersebut berupa tuturan imperatif dan tuturan interogratif dan tuturan deklaratif. Berikut ini adalah beberapa data tuturan imperatif yang diwujudkan dalam jenis implikatur percakapan umum.

\section{( Tuturan 31 )}

Dosen : “ Ibu biasanya ingin kelas kita lebih kondusif. Supaya kelas kita lebih enak mungkin bisa dilihat di bawah meja dan di bawah kursi kalian. Tidak usah ragu-ragu langsung ambil.“

Konteks : Dosen akan memulai perkuliahan tetapi melihat 
banyaknya sampah yang berserakan di lantai.

Analisis : Maksud dari tuturan tersebut adalah dosen akan memulai perkuliahan, tetapi melihat banyaknya sampah yang berserakan di lantai.

\section{( Tuturan 9 )}

Dosen : " Jangan main HP !"

Mahasiswa : "Dia bu yang main HP."

Konteks : Dosen melarang mahasiswa untuk bermain HP di dalam kelas.

Analisis : Maksud dari tuturan tersebut adalah dosen melarang mahasiswa untuk bermain HP di dalam kelas. Wujud interogratif memiliki tujuan untuk memberikan pertanyaan terhadap mitra tuturnya. Berikut ini adalah beberapa data tuturan interogratif yang diwujudkan dalam jenis implikatur percakapan umum.

\section{( Tuturan 3 )}

Dosen : "Punya rangkuman materinya ?" Mahasiswa : "Di rumah bu"

Konteks : Dosen bertanya kepada mahasiswa apakah memiliki rangkuman materi perkuliahan, tetapi mahasiswa menjawab "di rumah" yang menandakan jika mereka tidak punya atau tidak membawa.

Analisis: Maksud dari tuturan tersebut adalah Dosen bertanya kepada mahasiswa terkait rangkuman materi perkuliahan, tetapi mahasiswa menjawab di rumah yang menandakan jika mereka tidak punya atau tidak membawa.

\section{( Tuturan 38 )}

Dosen : " Bagaimana mau dilanjutkan atau tidak materinya?"

Mahasiswa : "Mau bu."
Konteks : Dosen menyuruh mahasiswa untuk tenang memperhatikan materi yang disampaikan

Pada analisis implikatur percakapan umum terdapat wujud tuturan deklaratif dengan fungsi komuikatif untuk meyampaikan sebuah informasi.

\section{( Tuturan 25 )}

Dosen : "Yang tidak bisa, tanya yang bisa. Yang bisa bantu yang tidak bisa."

Konteks : Dosen menyuruh membuat kelompok dalam mengerjakan tugas, dan mengintruksikan untuk saling membantu.

Analisis : Maksud dari tuturan tersebut adalah Dosen menyuruh membuat kelompok dalam mengerjakan tugas, dan mengintruksikan untuk saling membantu.

\section{( Tuturan 18 )}

Dosen : " Silahkan yang dibelakang mau ke depan, di depan masih kosong."

Mahasiswa : "Iya bu."

Konteks : Dosen menyuruh beberapa Mahasiswanya untuk maju ke depan mengisi sebagian kursi yang kosong.

Analisis :Maksud dari tuturan tersebut adalah dosen menyuruh beberapa mahasiswanya untuk maju ke depan mengisi sebagian kursi yang kosong.

Faktor - faktor yang melatarbelakangi munculnya implikatur percakapan dalam proses pembelajaran bahasa Indonesia pada Program Studi Akuntasi Semester I FEB Unmas Denpasar meliputi: bahasa, kepekaan, keakraban, budaya, kepedulan dan kasih sayang. Faktor bahasa dikatakan melatar belakangi munculnya implikatur percakapan karena bahasa yang dipergunakan sehari-hari secara umum sama, yaitu bahasa Indonesia. Keakraban yang terjadi di dalam kelas juga 
mampu memunculkan implikatur percakapan. Keakraban bisa terjadi akibat intensitas pertemuan yang dilakukan secara berkelanjutan antara dosen dan mahasiswa. Faktor Kepekaan yang digunakan dosen dalam proses pembelajaran adalah untuk melatih kepekaan mahasiswa. Peranan dosen dalam proses pembelajaran sangat berpengaruh terhadap sikap sosial mahasiswa. Hal ini dapat dilihat pada interaksi antara dosen dengan mahasiswa dalam proses pembelajaran. Dalam pembelajaran dosen harus melatih sikap sosial mahasiswa dalam melakukan interaksi dengan efektif kepada lingkungan sosial di kampus maupun pergaulan dalam masyarakat. Faktor budaya menjadi salah satu faktor yang melatarbelakangi terjadinya implikatur percakapan dalam proses pembelajaran karena budaya yang kuat ditanamkan oleh lingkungan sekitar kepada mahasiswa yang bersangkutan. Faktor kepedulian dan kasih sayang menjadi salah satu faktor munculnya implikatur percakapan karena seorang dosen/pendidik ingin selalu mendidik serta menanamkan karakter yang mulia kepada mahasiswa.

\section{SIMPULAN DAN SARAN}

Wujud implikatur percakapan yang ditemukan dalam pembelajaran bahasa Indonesia Pada Program Studi Akuntansi Semester I FEB Unmas Denpasar terdiri dari 4 implikatur yaitu implikatur konvensional, implikatur umum, implikatur khusus dan implikatur percakapan berskala. Faktor - faktor yang memunculkan implikatur dalam pembelajaran yaitu: bahasa, keakraban, kepekaan, budaya, kepedulian dan kasih sayang.

Hasil penelitian ini diharapkan dapat memberikan informasi kepada dosen dan mahasiswa bahwa penggunaan implikatur dalam percakapan dapat menjaga hubungan baik dan memiliki kesan lebih sopan dalam pergaulan, serta penelitian ini diharapkan dapat dijadikan pertimbangan bagi peneliti lain dalam memperkaya kajian penelitian bahasa Indonesia khususnya mengenai implikatur percakapan.

\section{DAFTAR PUSTAKA}

Geoffrey, L. (1993). Prinsi-Prinsip Pragmatik Terjemahan oleh MDD Oka. Jakarta: Penerbit Universitas Indonesia.

Rusminto, N. E. (2009). Analisis Wacana Bahasa Indonesia (Buku Ajar). Bandar Lampung: Universitas Lampung.

Yuniarti, N. (2016). Implikatur percakapan dalam percakapan humor. Jurnal Pendidikan Bahasa, 3(2), 225-240. 